\title{
New lichen records from the mountain forests of Southern Siberia
}

\author{
I. Urbanavichene ${ }^{1}$, Z. Palice ${ }^{2}$, G. Urbanavichus ${ }^{3}$ \\ ${ }^{1}$ Komarov Botanical Institute RAS, Professor Popov Str. 2, St Petersburg, 197376, Russia; \\ Baikal State Nature Biosphere Reserve, Krasnogvardeiskay Str. 34, Tankhoi, Republic of Buryatia, 671220, Russia. E-mail: \\ urbanavichene@gmail.com \\ ${ }^{2}$ Institute of Botany, Academy of Sciences of the Czech Republic, Průhonice, CZ-252 43, Czech Republic. \\ E-mail: zpalice@yahoo.com \\ ${ }^{3}$ Institute of North Industrial Ecology Problems, Kola Science Centre RAS, Akademgorodok 14a, Apatity, 184209, \\ Murmansk Region, Russia.E-mail: g.urban@mail.ru
}

Keywords: Baikal Reserve, Biatorella flavella, Khamar-Daban Range, lichens, new records, Russia, Western Sayan Mts.

Summary. Based on the results of field works mainly in 2009-2017, new data on new and noteworthy lichen species from Southern Siberia are presented. The lichen specimens were collected predominantly by the first author in the mountain dark coniferous forests with Abies sibirica, Pinus sibirica, Populus suaveolens, Sorbus sibirica and Padus avium in Baikal State Nature Biosphere Reserve (Khamar-Daban Range, Republic of Buryatia) and Ergaki Nature Park (Western Sayan Mts, Krasnoyarsk Territory). In the present paper, 14 species are reported as new for the lichen flora of study areas, among them: Biatorella flavella is reported for the first time for Russia, Ropalospora viridis is new to Asia, 5 species - Bryoria vrangiana, Dictyocatenulata alba, Elixia flexella, Lecanora compallens and Micarea soralifera - are new for Siberia, Chaenotheca subroscida and Fuscidea arboricola are new for Southern Siberia, 4 species - Absconditella annexa, Caloplaca sorocarpa, Bryobilimbia sanguineoatra and Protothelenella sphinctrinoidella are new for Baikal Siberia, Caloplaca sorocarpa is new for Krasnoyarsk Territory, Pilophorus strumaticus is new for Republic of Buryatia. A full text of herbarium labels, some comments and comparisons with similar species are given. The information about distribution of all mentioned species in Russia and world is also presented. Our records considerably extend the ranges or fill gaps in the formerly disjunctive distributions of these species.

\section{Новые находки лишайников из горно-таежных лесов Южной Сибири}

\author{
И. Урбанавичене ${ }^{1}$, 3. Палице 2 , Г. Урбанавичюс ${ }^{3}$ \\ ${ }^{\prime}$ Ботанический институт им. В. Л. Комарова РАН, ул. Проф. Попова, д. 2, г. Санкт-Петербург, 197376, Россия; \\ Байкальский государственный природный биосферный заповедник, Кабанский р-он, \\ пос. Танхой, 671220, Республика Бурятия, Россия \\ ${ }^{2}$ Институт Ботаники Академии наук Чешской Республики, Прухонице, CZ-252 43, Чешская Республика \\ ${ }^{3}$ Институт проблем промышленной экологии Севера, ФИЦ КНЦ РАН, Академгородок, $14 a$, \\ Aпатиты, 184209, Мурманская обл., Россия
}

Ключевые слова: Байкальский заповедник, Западный Саян, лишайники, новые находки, Россия, Хамар-Дабан, Biatorella flavella. 
Аннотация. Несмотря на многолетнее изучение видового разнообразия лишайников Южной Сибири и Прибайкалья, видовой состав лихенофлоры этих регионов ежегодно пополняется новыми видами, выявленными при проведении экспедиционных лихенологических исследований. Представленное дополнение к лихенофлоре Байкальского заповедника (хр. Хамар-Дабан, Республика Бурятия) и Природного парка «Ергаки» (Западный Саян, Красноярский край) включает виды, новые как для Республики Бурятии или Красноярского края, так и для более крупных регионов. Biatorella flavella впервые приводится для России, Ropalospora viridis для Азии, Bryoria vrangiana, Dictyocatenulata alba, Elixia flexella, Lecanora compallens, Micarea soralifera новые для Сибири, Chaenotheca subroscida, Fuscidea arboricola - для Южной Сибири, Absconditella annexa, Caloplaca sorocarpa, Bryobilimbia sanguineoatra и Protothelenella sphinctrinoidella - для Байкальской Сибири, Caloplaca sorocarpa - для Красноярского края, Pilophorus strumaticus - для Бурятии. Все лишайники собраны в горно-лесных местообитаниях, в условиях влажного, мягкого климата, где главным типом растительности являются бореальные леса, а именно, горная тайга в ее южном варианте - темнохвойные леса с Abies sibirica, Pinus sibirica и участием Sorbus sibirica, Populus suaveolens и Padus avium.

The lichen flora of the Southern Baikal region (the Khamar-Daban Range and Baikal State Nature Biosphere Reserve) has been actively studied during the last 30 years (Trass et al., 1988; Pärn, Trass, 1990; Randlane, Saag, 1991; Urbanavichene, 1996, 1998, 2001, 2015; Urbanavichene, Urbanavichus, 1998, 1999a, b, c; Urbanavichus, Urbanavichene, 2003; Urbanavichus, 2007; Urbanavichus et al., 2007; Urbanavichene, Palice, 2016). But, the lichen species diversity of this region and of the Baikal State Nature Reserve is still not fully revealed, as suggested by additions to the species list resulted from annual expeditions.

The current list includes 14 species collected from the mountain forest territories of Southern Siberia - Baikal State Nature Biosphere Reserve (Republic of Buryatia) and Ergaki Nature Park (Krasnoyarsk Territory). Studied nature protected areas are situated in the southern part of Siberia in the forest zone of Western Sayan Mts and Khamar-Daban Range. The climate of both regions is very humid and mild, with an annual precipitation about 1000 $\mathrm{mm}$ and a mean annual temperature of $0.7^{\circ} \mathrm{C}$. The studied territories lie $670-1600 \mathrm{~m}$ above sea level. The main vegetation type is boreal forests (taiga), namely mountain taiga in its southern variant: with Abies sibirica Ledeb., Pinus sibirica Du Tour, Populus suaveolens Fisch., Sorbus sibirica Hedl. and Padus avium Mill. All forests are old-growth and have never been cut down.

The specimens for the present study were collected by I. Urbanavichene (August 2013, 2016, 2017 - in Baikal Reserve; August 2009 and July 2010 - in Ergaki Nature Park) and by G. Urbanavichus (August 2002 - in Baikal Reserve).

Sorediate specimens were studied for chemistry by TLC following the procedure by Orange et al. (2010) and spot-tests with K (10\% potassium hydroxide in water), $\mathrm{C}$ (saturated solution of calcium hypochlorite) and $\mathrm{Pd}$ (paraphenylendiamine).
Absconditella annexa (Arnold) Vězda: "Russia, Republic of Buryatia, Kabanskiy distr., Baikal Reserve, Khamar-Daban Range, upper course of the Osinovka River (Mishikhinskoe lesnichestvo), subalpine belt, $1420 \mathrm{~m}, 51^{\circ} 31^{\prime} 07.0^{\prime \prime} \mathrm{N}, 105^{\circ} 24^{\prime} 34.5^{\prime \prime} \mathrm{E}$, on soil and mosses over boulder (on the path of Ochotona alpine Pallas). 17 VIII 2017. I. N. Urbanavichene" (LE L14949).

Note: Species is new to Baikal Siberia. In Russia, it was previously known from the European North and the Altai Mts (Melekhin, 2009; Sedelnikova, 2017). Until recently, this relatively rare species was known only from Europe (Coppins, 2009).

Biatorella flavella (Nyl.) Lettau: "Russia, Krasnoyarsk Territory, Ermakovskiy distr., Western Sayan Mts, Ergaki Nature Park, $0.5 \mathrm{~km}$ above the Bagazul' River, the slope of the east exposition, Pinus sibirica and Abies sibirica forest, $53^{\circ} 01^{\prime} 16.7^{\prime \prime} \mathrm{N}$, $93^{\circ} 13^{\prime} 27.8^{\prime \prime} \mathrm{E}$, on the wood of Pinus sibirica. $17 \mathrm{VII}$ 2010. I. N. Urbanavichene" (LE L14950).

Note: Species is new to Russia. This is poorly known lichen, recorded only few times in Central Europe mainly on decaying Sphagnum sp. (Poelt, Vězda, 1977), but originally described from wood of Larix trunk (Nylander, 1885).

Its brightly yellow-green pruinose ascomata resemble those of Thelocarpon Nyl., but they are more flat in Biatorella flavella, and examined asci were referable to the Strangospora-type sensu Hafellner (1995). Asci polyspored (to $\sim 100$ ascospores), Strangospora-type $(38-50 \times 15-20 \mu)$, paraphyses simple, ascospores globose, up to $2.5 \mu$ diam.

Bryobilimbia sanguineoatra (Wulfen) Fryday et al.: "Russia, Republic of Buryatia, Kabanskiy distr., Baikal Reserve, Khamar-Daban Range, basin of the Osinovka River (Mishikhinskoe lesnichestvo), Pinus sibirica and Abies sibirica forest, 670 $\mathrm{m}, 51^{\circ} 33^{\prime} 44.8^{\prime \prime} \mathrm{N}, 105^{\circ} 23^{\prime} 44.7^{\prime \prime} \mathrm{E}$, on the bark of the 
dead Abies sibirica. 18 VIII 2017. I. N. Urbanavichene" (LE L14962).

NotE: Species is new to Baikal Siberia. Probably it is a circumboreal species. The distribution of this species in Russia requires additional investigations because it was previously treated as a synonym of Mycobilimbia hypnorum (Lib.) Kalb et Hafellner. $B$. sanguineoatra has recently been reported from Republic of Mordovia (Urbanavichene, Urbanavichus, 2015), Republic of Adygea (Otte, 2001, as Mycobilimbia sanguineoatra (Wulfen) Kalb et Hafellner). The species Lecidea sanguineoatra auct. previously reported from some localities in Russia, e. g. Leningrad and Moscow Regions (Tomin, 1956), Magadan Region (Korolev, Tolpysheva, 1980), Altai Territory (Davydov, Printzen, 2012) might also belong to Bryobilimbia sanguineoatra (Wulfen) Fryday et al.

Paraphyses $1.7 \mathrm{~mm}$ wide, simple, ascospores simple, with finely warted perispore, $8-10 \times 3.3-5$ $\mu$ (in a close species Bryobilimbia hypnorum (Lib.) Fryday et al. ascospores often 1-septate and wide, to 6-7 $\mu$ ) (Fryday et al., 2014).

Bryoria vrangiana (Gyeln.) Brodo et D. Hawksw.: "Russia, Republic of Buryatia, Kabanskiy distr., Baikal Reserve, Khamar-Daban Range, upper course of the Osinovka River (Mishikhinskoe lesnichestvo), Abies sibirica-Pinus sibirica forest, 1230 $\mathrm{m}, 51^{\circ} 31^{\prime} 42.4^{\prime \prime} \mathrm{N}, 105^{\circ} 24^{\prime} 45.9^{\prime \prime} \mathrm{E}$, on branches in the upper part of the crown of Abies sibirica. 17 VIII 2017. I. N. Urbanavichene" (LE L14951, ALTB).

Note: Species is new to Siberia. Most likely it is a circumboreal species. The distribution of this species in the world and Russia requires additional investigations because it was previously treated as a synonym of Bryoria implexa (Hoffm.) Brodo et D. Hawksw. In Russia, Bryoria vrangiana has recently been reported from the Republic of Karelia and Arkhangelsk Region (Tarasova et al., 2015, 2016) and Moscow Region (Czernyadjeva et al., 2018).

Branches are often with a few blackened fragmentation areas, usually slightly shiny, mainly even, may become twisted and compressed. Pseudocyphellae inconspicuous, brownish white, mainly elongate fusiform, mostly plane. Thallus $\mathrm{K}-, \mathrm{C}+$ red, $\mathrm{KC}+$ red, PD-; TLC: gyrophoric acid (Chemotype 1) (Velmala et al., 2014).

Caloplaca sorocarpa (Vain.) Zahlbr.: "Russia, Krasnoyarsk Territory, Ermakovskiy distr., Western Sayan Mts, Ergaki Nature Park, Pinus sibirica and Abies sibirica forest near Oiskoe Lake, $53^{\circ} 50^{\prime} 07.0^{\prime \prime} \mathrm{N}, 93^{\circ} 14^{\prime} 38.0^{\prime \prime} \mathrm{E}$, on the bark of Lonicera altaica. 02 VIII 2009. I. N. Urbanavi- chene"; "Russia, Republic of Buryatia, Baikal Reserve, Khamar-Daban Range, upper course of the Osinovka River (Mishikhinskoe lesnichestvo), $1480 \mathrm{~m}, 51^{\circ} 31^{\prime} 40.0^{\prime \prime} \mathrm{N}, 105^{\circ} 25^{\prime} 11.0^{\prime \prime} \mathrm{E}$, on the bark of Lonicera turczaninowii. 17 VIII 2017. I. N. Urbanavichene" (LE L14952, ALTB).

Note: Species is new to Baikal Siberia and Krasnoyarsk Territory. The species was previously known in Southern Siberia from the Altai Mts (Davydov, Printzen, 2012). In Russia it was reported from Murmansk Region (Frolov, Konoreva, 2016), Republic of Komi (Pystina, 2003), Kamchatka Peninsula (Khodosovtsev et al., 2004). This relatively rare species has been reported from Europe, North America and Asia (Davydov, Printzen, 2012). It is known from Europe, Asia and North America (Khodosovtsev et al., 2004).

Brownish-tinged external soredia and not excavate greenish-gray circular soralia, distinctly elevated above the thallus are diagnostic for Caloplaca sorocarpa (in a close species C. ulcerosa Coppins et P. James and C. obscurella (Lahm ex Körber) Th. Fr. soralia are excavate, not circular and distinctly elevated above the thallus).

Chaenotheca subroscida (Eitner) Zahlbr.: "Russia, Republic of Buryatia, Kabanskiy distr., Baikal Reserve, Khamar-Daban Range, upper course of the Osinovka River (Mishikhinskoe lesnichestvo), Pinus sibirica and Abies sibirica forest, $1230 \mathrm{~m}$, $51^{\circ} 31^{\prime} 42.4^{\prime \prime} \mathrm{N}, 105^{\circ} 24^{\prime} 45.9^{\prime \prime} \mathrm{E}$, on the wood of the tree Abies sibirica. 13 VIII 2013. I. N. Urbanavichene" (LE L14953).

Note: Species is new to Southern Siberia. This sub-circumboreal species with a scattered distribution was recorded in Russia from the European North and Centre, Ural Mts and Western Siberia (Urbanavichus, 2010). This species occurs in Europe, Asia and North America (Tibell, Beck, 2002).

This species can be identified by its yellowish excipulum and upper stalk of the apothecium, greyish, minutely granular thallus, platy-cracked, globose spores and slender stalk. It is very closely related to C. phaocephala (Turner) Th. Fr. The two species are nearly identical in appearance, but in contrast to the slender stalk and pale gray granular thallus of C. subroscida, the apothecium in C. phaocephala has a more robust stalk, the total length of the apothecium is $6-15$ times greater than the central stalk width, and the thallus is brownish-green and scalelike or squamulose (Tibell, Beck, 2002).

Dictyocatenulata alba Finley et E. F. Morris: "Russia, Republic of Buryatia, Kabanskiy distr., Bai- 
kal Reserve, Khamar-Daban Range, lower course of the Anosovka River, Pinus sibirica and Abies sibirica forest, $533 \mathrm{~m}, 51^{\circ} 29^{\prime} 15.0^{\prime \prime} \mathrm{N}, 105^{\circ} 00^{\prime} 48.0^{\prime \prime} \mathrm{E}$, on mossy bark of Sorbus sibirica. 29 VIII 2017. I. N. Urbanavichene" (LE L14954, ALTB).

NotE: Species is new to Siberia. This is the third finding of the species for the lichen biota of Russia, being previously recorded in the Far East - Primorye Territory (Diederich et al., 2008) and in Leningrad Region (Stepanchikova et al., 2010). D. alba is rather widespread in tropical, subtropical, broadleaved zones and known from Central and Eastern Europe, Asia, North and Central America.

Ascomata unknown. Conidiomata are synnematous, pale, sessile to long stipitate up to $1.5 \mathrm{~mm}$ tall; stipe cream coloured, smooth, $25-175 \mu$ in diam.; upper zone forming muriform conidia is purely white. Photobiont is trentepohlioid (Diederich et al., 2008). The species grows usually at shaded basal parts of deciduous trees in more humid microsites.

Elixia flexella (Ach.) Lumbsch: "Russia, Republic of Buryatia, Kabanskiy distr., Baikal Reserve, Khamar-Daban Range, basin of the Osinovka River (Mishikhinskoe lesnichestvo), Pinus sibirica and Abies sibirica forest, $1370 \mathrm{~m}, 51^{\circ} 31^{\prime} 42.5^{\prime \prime} \mathrm{N}$, $105^{\circ} 25^{\prime} 01.1^{\prime \prime E}$, on the lignum of Abies sibirica. 16 VIII 2016. I. N. Urbanavichene" (LE L14960).

NotE: Species is new to Siberia. Elixia flexella is temperate-boreal species; it is known from scattered records in Europe, Asia and North America (Spribille, Björk, 2008). In Russia, the species has scattered distribution in the European North and Centre (e.g. Fadeeva et al., 2007; Notov et al., 2011), Northern and Subpolar Ural Mts (Hermansson et al., 2006; Sedelnikova, 2017), Northern Caucasus (Urbanavichus, Ismailov, 2013) and Far East (Chabanenko, 2002).

Habitually it resembles some non-lichenized genera with hysterothecioid ascomata (e.g. Durella, Hysterium). Elixia flexella is characterized by prolonged to almost orbicular apothecia with jet black margin elevated above the disc level, often appearing gyrose and inrolled. The disc becomes more open with age, unlike the similar species Ptychographa xylographoides Nyl. which has permanently slit-like discs. Both species grow in hard conifer wood and form inapparent thallus composed of dispersed tiny brownish granules among wood fibers, best visible when the substrate is moistened.

Fuscidea arboricola Coppins et Tønsberg: "Russia, Republic of Buryatia, Kabanskiy distr.,
Baikal Reserve, Khamar-Daban Range, basin of the Osinovka River (Mishikhinskoe lesnichestvo), Pinus sibirica and Abies sibirica forest, $670 \mathrm{~m}$, $51^{\circ} 33^{\prime} 44.8^{\prime \prime} \mathrm{N}, 105^{\circ} 23^{\prime} 44.7^{\prime \prime} \mathrm{E}$, on the bark of Abies sibirica. 18 VIII 2017. I. N. Urbanavichene" (LE L14955, ALTB).

NotE: Species is new to Southern Siberia. It is widespread in Europe and Eastern North America, but rare reported from Asia. In Russia, the species is widespread in the European North and Centre, Ural Mts (Urbanavichus, 2010), and was reported from Western Siberia (Paukov, Mikhailova, 2011), Eastern Siberia (Zhdanov, 2012) and from Caucasus (Urbanavichus, Urbanavichene, 2014).

It is characterized by having small grayish/greenish circular sorediate thalli (with a yellowish tint) up to $5 \mathrm{~cm}$ in diam., surrounded by a distinct brown prothallus which may give an overall brown appearance (Tønsberg, 1992). KOH + brownish-yellow, $\mathrm{Pd}+$ rust red, UV-; TLC: fumarprotocetraric acid.

Lecanora compallens Herk et Aptroot: "Russia, Republic of Buryatia, Kabanskiy distr., Baikal Reserve, Khamar-Daban Range, basin of the Osinovka River (Mishikhinskoe lesnichestvo), Pinus sibirica and Abies sibirica forest, $670 \mathrm{~m}, 51^{\circ} 33^{\prime} 44.8^{\prime \prime} \mathrm{N}$, $105^{\circ} 23^{\prime} 44.7^{\prime \prime} \mathrm{E}$, on the bark of Abies sibirica. 18 VIII 2017. I. N. Urbanavichene" (LE L14956).

NotE: Species is new to Siberia. This poorly known sterile sorediate species is widespread in Europe (Van Herk, Aptroot, 1999; Tsurykau et al., 2014) and once was reported from the SouthWestern Asia - Turkey (Yazıc1, Aptroot, 2008). In Russia it was reported only from the European part - Leningrad, Yaroslavl and Ryazan Regions (Stepanchikova et al., 2011; Muchnik, Śliwa, 2013).

Soralia punctiform, $0.1-0.3 \mathrm{~mm}$, soredia granular, $15-30 \mu$ diam., $\mathrm{K}+$ yellow to yellowbrown, $\mathrm{UV} \pm$ pale orange; TLC: usnic acid, zeorin. L. compallens is very similar to L. expallens Ach., which differs by the presence of xanthones (van Herk, Aptroot, 1999).

Micarea soralifera Guzow-Krzem. et al.: "Russia, Republic of Buryatia, Kabanskiy distr., Baikal Reserve, Khamar-Daban Range, the middle course of the Anosovka River, Pinus sibirica and Abies sibirica forest on the slope, $590 \mathrm{M}, 51^{\circ} 26^{\prime} 16.0^{\prime \prime} \mathrm{N}$, $105^{\circ} 02^{\prime} 45.0^{\prime \prime} \mathrm{E}$, on wood of deciduous trees. $29 \mathrm{VIII}$ 2017. I. N. Urbanavichene" (LE L14957).

Note: Species is new to Siberia. It is the second finding for the lichen flora of Russia, formerly the species was found only in the Northern Caucasus 
(Urbanavichus, Urbanavichene, 2017). A newly described species has been known from Poland and the Czech Republic (Guzow-Krzemińska et al., 2016) and has been recently reported from Sweden (Svensson et al., 2017).

Sorediate species belonging to the $M$. prasinagroup is characterized by initially delimited soralia developing directly from the endoxylic thallus or small external areoles, as well as the presence of micareic acid (Guzow-Krzemińska et al., 2016).

Pilophorus strumaticus Nyl. ex Cromb.: "Russia, Republic of Buryatia, Kabanskiy distr., Baikal Reserve, Khamar-Daban Range, basin of the Pereemnaya River, the mouth of Nemsky Klyuch River, the left bank, c. $680 \mathrm{~m}, 51^{\circ} 25^{\prime} 00.0^{\prime \prime} \mathrm{N}$, $105^{\circ} 17^{\prime} 38.0^{\prime \prime} \mathrm{E}$, on above-water surface of boulders. 11 VIII 2002. G. P. Urbanavichus" (LE L14961).

NotE: Species is new to Republic of Buryatia. It was reported for Russia from North-Western part (Ahti, Stenroos, 2013), Republic of Sakha (Yakutia) and Trans-Baikal Territory (Chesnokov et al., 2017). The world distribution: British Isles, Northern Europe, Siberia (Ahti, Stenroos, 2013).

It is characterized by the pin-shaped pseudopodetia with terminal, black, \pm spherical apothecia.

Protothelenella sphinctrinoidella (Nyl.) H. Mayrhofer et Poelt: "Russia, Republic of Buryatia, Kabanskiy distr., Baikal Reserve, Khamar-Daban Range, upper course of the Osinovka River (Mishikhinskoe lesnichestvo), subalpine belt, 1420 $\mathrm{m}, 51^{\circ} 31^{\prime} 07.0^{\prime \prime} \mathrm{N}, 105^{\circ} 24^{\prime} 34.5^{\prime \prime} \mathrm{E}$, on soil and mosses over boulder (on the path of pika-Ochotona alpina). 17 VIII 2017. I. N. Urbanavichene" (LE L14959).

Note: Species is new to Baikal Siberia. This arctic-alpine to boreal-montane bryophilous species is known in Russia from Arctic, European North and Centre, Siberia and Far East (Urbanavichus, 2010). World distribution: arctic zone and mountains of
Europe, Asia, North America (Mayrhofer, 2002). It was also reported from Antarctic (Øvstedal, Smith, 2001).

This species is characterized by an indistinct thallus, small sessile black perithecia with a dull greenish exciple and elongate submuriform ascospores. Another species known from Southern Siberia is P. sphinctrinoides (Nyl.) H. Mayrhofer et Poelt, which is distinguished by larger partly immersed perithecia and larger muriform ascospores (Mayrhofer, 2002).

Ropalospora viridis (Tønsberg) Tønsberg: "Russia, Republic of Buryatia, Kabanskiy distr., Baikal Reserve, Khamar-Daban Range, basin of the Osinovka River (Mishikhinskoe lesnichestvo), Pinus sibirica and Abies sibirica forest, $670 \mathrm{~m}$, $\mathrm{N} 51^{\circ} 33^{\prime} 44.8^{\prime \prime} \mathrm{N}, 105^{\circ} 23^{\prime} 44.7^{\prime \prime} \mathrm{E}$, on the bark of Abies sibirica. 18 VIII 2017. I. N. Urbanavichene" (LE L14958).

Note: Species is new to Asia. In Russia, the species has a scattered distribution in European part from Kaliningrad Region to Ural Mts (Urbanavichus, 2010). $R$. viridis is common and widely distributed throughout Europe and North America (e.g. Tønsberg, 1992; Lendemer, 2011).

This species forms a grayish-green areolate thallus with bright green, usually confluent soralia arising from the apices of the areoles. Thallus and soralia $\mathrm{C}-, \mathrm{K}-, \mathrm{Pd}-, \mathrm{UV}+$ white; TLC: perlatolic acid. $R$. viridis can be confused with sterile Fuscidea arboricola and F. pusilla Tønsberg, but they differ chemically in containing fumarprotocetraric acid and divaricatic acid, respectively.

\section{Acknowledgment}

The study of the first author was carried out within the framework of the Program of basic research of the Russian Academy of Sciences, project "Biological diversity and dynamics of the flora and vegetation of Russia", 0126-2018-0027).

\section{REFERENCES / ЛИТЕРАTУРА}

Ahti T., Stenroos S. 2013. Pilophorus. In: Nordic Lichen Flora. Vol. 5. Eds. T. Ahti, S. Stenroos, R. Moberg. The Nordic Lichen Society, Uddevalla, 87-89 pp.

Chabanenko S. I. 2002. Checklist of the flora of lichens in the south of the Russian Far East. Dalnauka, Vladivostok, 232 pp. [In Russian]. (Чабаненко С. И. Конспект флоры лишайников юга Российского Дальнего Востока. Владивосток: Дальнаука, 2002. 232 с.).

Chesnokov S. V., Konoreva L. A., Poryadina L. N., Paukov A. G., Kusnetsova E. S., Andreev M. P., Gagarina $\boldsymbol{L}$. V. New and interesting lichen records for Republic of Sakha (Yakutia). III. Novosti sistematiki nizshikh rasteniy [Novit. Syst. Pl. non Vasc.] 51: 220-231 [In Russian]. (Чесноков С. В., Конорева Л. А., Порядина Л. Н., Пауков A. Г., Кузнецова Е. С., Андреев М. П., Гагарина Л. В. Новые и интересные находки лишайников для Республики Саха (Якутия). III // Новости сист. низш. раст., 2017. Т. 51. С. 220-231). 
Coppins B. J. 2009. Absconditella Vězda. In: The Lichens of Great Britain and Ireland. Eds. C. W. Smith, A. Aptroot, B. J. Coppins, A. Fletcher, O. L. Gilbert, P. W. James, P. A. Wolseley. British Lichen Society, London, 123-124 pp.

Czernyadjeva I. V. (ed.), Kotkova V. M., Zemlyanskaya I. V., Novozhilov Yu. K., Vlasenko A. V., Vlasenko V. A., Blagoveshchenskaya E. Yu., Georgieva M. L., Notov A. A., Himelbrant D. E., Muchnik E. E., Urbanavichene I. N., Aristarkhova E. A., Bocharnikov M. V., Ismailov A. B. 2018. New cryptogamic records. 2. Novosti sistematiki nizshikh rasteniy [Novit. Syst. Pl. non Vasc.] 52(1): 209-223 [In Russian]. (Чернядвева И. В., Коткова В. М., Землянская И. В., Новожилов Ю. К., Власенко А. В., Благовещенская Е. Ю., Георгиева М. Л., Нотов А. А., Гимельбрант Д. Е., Мучник Е. Э., Урбанавичене И. Н., Аристархова Е. А., Бочарников М. В., Исмаилов $\boldsymbol{A}$. $\boldsymbol{Б}$. Новые находки водорослей, грибов, лишайников и мохообразных. 2 // Новости сист. низш. раст., 2018. 52(1). C. 209-223).

Davydov E. A., Printzen C. 2012. Rare and noteworthy boreal lichens from the Altai Mountains (South Siberia, Russia). Bryologist 115(1): 61-73. DOI: https://doi.org/10.1639/0007-2745.115.1.61

Diederich P., Palice Z., Ertz D. 2008. Cheiromycina ananas is a synonym of Dictyocatenulata alba, a widespread, lichenized, synnematous hyphomycete herewith reported as new for Europe. Sauteria 15: 205-214.

Fadeeva M. A., Golubkova N. S., Vitikainen O., Ahti T. 2007. Synopsis of lichens and lichenicolous fungi of the Republic of Karelia. Petrozavodsk, 194 pp. [In Russian]. (Фадеева М. А., Голубкова Н. С., Витикайнен О., Ахти Т. Конспект лишайников и лихенофильных грибов Республики Карелия. Петрозаводск, 2007. 194 с.).

Frolov I., Konoreva L. 2016. New records of crustose Teloschistaceae (lichens, Ascomycota) from the Murmansk region of Russia. Polish Polar Research 37(3): 421-434. DOI: https://doi.org/10.12697/fce.2017.54.04

Fryday A. M. 2008. The genus Fuscidea (Fuscideaceae, lichenized Ascomycota) in North America. Lichenologist 40(4): 295-328. DOI: https://doi.org/10.1017/S0024282908007755

Fryday A. M., Printzen C., Ekman S. 2014. Bryobilimbia, a new generic name for Lecidea hypnorum and closely related species. Lichenologist 46(1): 25-37. DOI: https://doi.org/10.1017/S0024282913000625

Guzow-Krzemińska B., Czarnota P., Lubek A., Kukwa M. 2016. Micarea soralifera sp. nov., a new sorediate species in the M. prasina group. Lichenologist 48(3): 161-169. DOI: https://doi.org/10.1017/S0024282916000050

Hafellner J. 1995. Towards a better circumscription of the Acarosporaceae (Lichenized Ascomycotina, Lecanorales). Cryptogamic Botany 5: 99-104.

Hermansson Ya.-O., Pystina T. N., Ove-Larsson B., Zhurbenko M. P. 2006. Lichens and Lichenicolous Fungi of the Pechoro-Ilychski Nature Reserve. Flora i fauna zapovednikov [Flora and fauna of reserves] 109: 79 [In Russian]. (Херманссон Я.-О., Пыстина Т. Н., Ове-Ларссон Б., Журбенко М. П. Лишайники и лихенофильные грибы Печеро-Илычского заповедника // Флора и фауна заповедников, 2006. Вып. 109. 79 с.).

Khodosovtsev A., Kuznetzova E., Himelbrant D. 2004. Lichen genus Caloplaca on the Kamchatka peninsula (Russia Far East). Botanica Lithuanica 10(3): 195-208.

Korolev Yu. B., Tolpysheva T. Yu. 1980. Outline of the lichen flora of the field station “Contact” (The Upper Kolyma Upland). Novosti sistematiki nizshikh rasteniy [Novit. Syst. Pl. non Vasc.] 17: 137-149 [In Russian]. (Королев Ю. Б., Толпышева T. Ю. Очерк флоры лишайников стационара «Контакт» (Верхнеколымское нагорье) // Новости сист. низш. раст., 1980. Т. 17. С. 137-149).

Lendemer J. C. 2011. A review of the morphologically similar species Fuscidea pusilla and Ropalospora viridis in eastern North America. Opuscula Philolichenum 9: 11-20.

Mayrhofer H. 2002. Protothelenella. In: Lichen Flora of the Greater Sonoran Desert Region. Vol. 1. Eds. T. H. Nash III, B. D. Ryan, C. Gries, F. Bungartz. Arizona State University, Tempe, 408-409 pp.

Melekhin A. V. 2009. Lichens from Lapland Nature Reserve new to Russia and Murmansk region. Bot. Zhurn. (Moscow \& St. Petersburg) 94(2): 289-291 [In Russian]. (Мелехин A. В. Новые для России и Мурманской области лишайники из Лапландского заповедника // Бот. журн., 2009. Т. 94, № 2. С. 289-291).

Muchnik E., Śliwa L. 2013. New and noteworthy lichen records from Central European Russia. Herzogia 26: 117-121. DOI: https://doi.org/10.13158/heia.26.1.2013.117

Notov A. A., Himelbrant D. E., Urbanavichus G. P. 2011. Annotated list of the lichen flora of the Tver region. Tver State University, Tver, 124 pp. [In Russian]. (Нотов А. А., Гимельбрант Д. Е., Урбанавичюс Г. П. Аннотированный список лихенофлоры Тверской области. Тверь: Твер. гос. ун-т, 2011. 124 с.).

Nylander W. 1885. Addenda nova ad Lichenographiam europaeam. Continuatio quadragesima quarta. Flora [Regensburg] 68(15): 295-301.

Orange A., James P. W., White F. J. 2010. Microchemical methods for the identification of lichens. British Lichen Society, London, $101 \mathrm{pp}$.

Otte V. 2001. Flechten und Moose im Gebiet des Bolschoi Tchatsch (NW-Kaukasus) - eine erste Übersicht, ergänzt durch einige von D. Benkert bestimmte Pezizales. Feddes Repertorium 112(7-8): 565-582. DOI: 10.1002/ fedr.4921120712

Ovstedal D. O., Smith R. I. L. 2001. Lichens of Antarctica and South Georgia. A Guide to Their Identification and Ecology. Cambridge University Press, Cambridge, 411 pp. 
Paukov A. G., Mikhailova I. N. 2011. Lichens of the "Samarovskiy Chugas" Nature Park (Western Siberia, Tyumen Region). Novosti sistematiki nizshikh rasteniy [Novit. Syst. Pl. non Vasc.] 45: 202-212 [In Russian]. (Пауков $\boldsymbol{A}$. Г., Михайлова И. Н. Лишайники природного парка «Самаровский Чугас» (Тюменская область) // Новости сист. низш. раст., 2011. Т. 45. С. 202-212).

Pärn A., Trass H. H. 1990. Epiphytic lichens of mountain forests of the Khamar-Daban mountain range (the Baikal region). Bot. Zhurn. (Moscow \& Leningrad) 75(3): 358-368 [In Russian]. (Пярн А., Трасс Х. Х. Эпифитные лишайники горных лесов хребта Хамар-Дабан (Прибайкалье) // Бот. журн., 1990. Т. 75, № 3. С. 358-368).

Poelt J., V̌̌zda A. 1977. Bestimmungsschlüssel europäischer Flechten. Ergänzungsheft I. Bibliotheca Lichenologica 9: 1-258.

Pystina T. N. 2003. Lishayniki tayezhnykh lesov yevropeyskogo Severo-Vostoka (podzony yuzhnoy i sredney taygi) [Lichens of the taiga forests of the European North-East (southern and middle taiga subzones)]. Ekaterinburg, 239 pp. [In Russian]. (Пыстина T. Н. Лишайники таежных лесов европейского Северо-Востока (подзоны южной и средней тайги). Екатеринбург, 2003. 239 с.).

Randlane T., Saag A. 1991. Chemical and morphological variation in the genus Cetrelia in the Soviet Union. Lichenologist 23(2): 113-126. DOI: https://doi.org/10.1017/S0024282991000282

Sedelnikova N. V. 2017. Species diversity of lichen biota of West Siberia and assess the involvement of lichen species in major mountain and lowland communities. Novosibirsk, 611 pp. [In Russian]. (Седельникова Н. В. Видовое разнообразие лихенобиоты Западной Сибири и оценка участия видов лишайников в основных ее горных и равнинных фитоценозах. Новосибирск, 2017. 611 с.).

Spribille T., Björk C. R. 2008. New records and range extensions in the North American lignicolous lichen flora. Mycotaxon 105: 455-468.

Stepanchikova I. S., Himelbrant D. E., Kukwa M., Kuznetsova E. S. 2011. New records of lichens and allied fungi from the Leningrad Region, Russia. II. Folia Cryptogamica Estonica 48: 85-94.

Stepanchikova I., Kukwa M., Kuznetsova E., Motiejūnaité J., Himelbrant D. 2010. New records of lichens and allied fungi from the Leningrad Region, Russia. Folia Cryptogamica Estonica 47: 77-84.

Svensson M., Ekman S., Klepsland J. T., Nordin A., Thor G., von Hirschheydt G., Jonsson F., Knutsson T. Lif M., Spribille T., Westberg M. 2017. Taxonomic novelties and new records of Fennoscandian crustose lichens. MycoKeys 25: 51-86. DOI: https://doi.org/10.3897/mycokeys.25.13375

Tarasova V. N., Sonina A. V., Androsova V. I., Ahti T. 2015. The lichens from the City of Petrozavodsk in the Herbarium of the Botanical Museum, University of Helsinki (H). Folia Cryptogamica Estonica 52: 41-50. DOI: http:// dx.doi.org/10.12697/fce.2015.52.06

Tarasova V. N., Sonina A. V., Androsova V. I., Stepanchikova I. S. 2016. The lichens of forest rocky communities of the hill Muroigora (Arkhangelsk Region, Northwest Russia). Folia Cryptogamica Estonica 53: 111-121. DOI: http://dx.doi.org/10.12697/fce.2016.53.13

Tibell L., Beck A. 2002. Morphological variation, photobiont association and ITS phylogeny of Chaenotheca phaeocephala and C. subroscida (Coniocybaceae, lichenized ascomycetes). Nordic Journal of Botany 21: 651-660. DOI: https://doi.org/10.1111/j.1756-1051.2001.tb00824.x

Tomin M. P. 1956. Opredelitel korkovykh lishaynikov Yevropeyskoy chasti SSSR (krome Kraynego Severa i Kryma) [Handbook of crustose lichens of the European part of the USSR (except Far North and Crimea)]. Minsk, 533 pp. [In Russian]. (Томин M. П. Определитель корковых лишайников Европейской части СССР (кроме Крайнего Севера и Крыма). Минск, 1956. 533 с.)

Tonsberg T. 1992. The sorediate and isidiate, corticolous, crustose lichens in Norway. Sommerfeltia 14: 1-331.

Trass H., Pärn A., Zobel K. 1988. Lichen indicational evaluation of the air pollution level in the southern Lake Baikal region. Acta et Commentationes Universitatis Tartuensis 812: 32-46.

Tsurykau A., Golubkov V, Kukwa M. 2014. New or otherwise interesting records of lichens and lichenicolous fungi from Belarus. Herzogia 27: 111-120. DOI: https://doi.org/10.13158/heia.27.1.2014.111

Urbanavichene I. N. 1996. Addition to the lichen flora of the Baikal Reservation. Bot. Zhurn. (Moscow \& St. Petersburg) 81(3): 137-144 [In Russian]. (Урбанавичене И. Н. Дополнения к флоре лишайников Байкальского заповедника // Бот. журн., 1996. Т. 81, № 3. С. 137-144).

Urbanavichene I. N. 1998. Catalogus lichenum reservati Baicalensis annotationibus praeditus. Novosti Sistematiki Nizshikh Rasteniy [Novit. Syst. Pl. non Vasc.] 32: 110-127 [In Russian]. (Урбанавичене И. Н. Аннотированный список лишайников Байкальского заповедника // Новости сист. низш. раст., 1998. Т. 32. С. 110-127).

Urbanavichene I. N. 2001. Ecology of epiphytic lichens growing on Abies sibirica along the south of Baikal. Bot. Zhurn. (Moscow \& St. Petersburg) 86(9): 80-91 [In Russian]. (Урбанавичене И. Н. Экология эпифитных лишайников, произрастающих на Abies sibirica Ledeb. в Южном Прибайкалье // Бот. журн., 2001. Т. 86, № 9. C. 80-91).

Urbanavichene I. N. 2015. The first record of Gyalideopsis helvetica (Graphidaceae, lichenized Ascomycota) for Russia from the southern part of Lake Baikal Region. Novosti Sistematiki Nizshikh Rasteniy [Novit. Syst. Pl. non 
Vasc.] 49: 282-288 [In Russian]. (Урбанавичене И. Н. Первая для России находка лишайника Gyalideopsis helvetica (Graphidaceae) из Южного Прибайкалья // Новости сист. низш. раст., 2015. Т. 49. С. 282-288).

Urbanavichene I. N., Palice Z. 2016. Rarely recorded lichens and lichen-allied fungi from the territory of the Baikal Reserve - additions for lichen flora of Russia. Turczaninowia 19, 1: 42-46. DOI: http://dx.doi.org/10.14258/ turczaninowia.19.1.5

Urbanavichene I. N., Urbanavichus G. P. 1998. Melanelia albertana (Lichenes) - a new for Russia species from the southern Baikal region. Bot. Zhurn. (Moscow \& St. Petersburg) 83(1): 130-131 [In Russian]. (Урбанавичене И. Н., Урбанавичюс Г. П. Melanelia albertana (Lichenes) - новый для России вид из Южного Прибайкалья // Бот. журн., 1998. Т. 83, № 1. С. 130-131).

Urbanavichene I. N., Urbanavichus G. P. 1999a. Ad lichenofloram jugi Chamar-Daban (regio Baicalensis australis). Novosti Sistematiki Nizshikh Rasteniy [Novit. Syst. Pl. non Vasc.] 33: 161-171 [In Russian]. (Урбанавичене И. Н., Урбанавичюс Г. П. К флоре лишайников хребта Хамар-Дабан (Южное Прибайкалье) // Новости сист. низш. раст., 1999. Т. 33. С. 161-171).

Urbanavichene I. N., Urbanavichus G. P. 1999b. Lichens on Populus suaveolens (Salicaceae) in southern Baikal region. Bot. Zhurn. (Moscow \& St. Petersburg) 84(1): 30-44 [In Russian]. (Урбанавичене И. Н., Урбанавичюс Г. П. Лишайники на Populus suaveolens (Salicaceae) в Южном Прибайкалье // Бот. журн., 1999. Т. 84, № 1. С. 30-44).

Urbanavichene I. N., Urbanavichus G. P. 1999c. New and rare for Asia and Russia lichens from the southern Baikal region. Bot. Zhurn. (Moscow \& St. Petersburg) 84(7): 129-133 [In Russian]. (Урбанавичене И. Н., Урбанавичюс Г. П. Новые и редкие для Азии и России лишайники из Южного Прибайкалья // Бот. журн., 1999. Т. 84, № 7. C. 129-133).

Urbanavichene I. N., Urbanavichus G. P. 2015. Additions to lichen flora of Mordovskii Reserve, Republic of Mordovia, and Middle Russia. Uchenyye zapiski Petrozavodskogo Gosudarstvennogo universiteta [Proceedings of Petrozavodsk State University] 8(153): 75-79 [In Russian]. (Урбанавичене И. Н., Урбанавичюс Г. П. Дополнения к лихенофлоре Мордовского заповедника, Республики Мордовия и Средней России // Ученые записки Петрозаводского государственного университета, 2015. № 8(153). С. 75-79).

Urbanavichus G. P. 2007. Physciella austrosibirica (Physciaceae, Ascomycota), a new lichen species from Southern Siberia. Bot. Zhurn. (Moscow \& St. Petersburg) 92(4): 88-91 [In Russian]. (Урбанавичюс Г. П. Physciella austrosibirica (Physciaceae, Ascomycota) - новый вид лишайника из Южной Сибири // Бот. журн., 2007. Т. 92 , № 4. C. 88-91).

Urbanavichus G. P. 2010. A checklist of the lichen flora of Russia. St. Petersburg, 194 pp.

Urbanavichus G., Ismailov A. 2013. The lichen flora of Gunib plateau, inner-mountain Dagestan (North-East Caucasus, Russia). Turkish Journal of Botany 37: 753-768. DOI: 10.3906/bot-1205-4

Urbanavichus G. P., Urbanavichene I. N. 2003. Micarea adnata (Micareaceae), a new to Siberia and Asia lichen species. Bot. Zhurn. (Moscow \& St. Petersburg) 88(3): 121-123 [In Russian]. (Урбанавичюс Г. П., Урбанавичене И. H. Micarea adnata (Micareaceae) - новый для Сибири и Азии вид лишайника // Бот. журн., 2003. Т. 88 , № 3. C. 121-123).

Urbanavichus G., Urbanavichene I. 2014. An inventory of the lichen flora of Lagonaki Highland (NW Caucasus, Russia). Herzogia 27(2): 285-319. DOI: https://doi.org/10.13158/heia.27.2.2014.285

Urbanavichus G. P., Urbanavichene I. N. 2017. Contribution to the lichen flora of Erzi Nature Reserve, Republic of Ingushetia, North Caucasus, Russia. Willdenowia 47(3): 227-236. DOI: https://doi.org/10.3372/wi.47.47306

Urbanavichus G. P., Urbanavichene I. N., Otnukova T. N. 2007. Phaeophyscia dissecta (Physciaceae, Lecanorales), a new lichen species from Southern Siberia (Russia). Bot. Zhurn. (Moscow \& St. Petersburg) 92(11): 118-123 [In Russian]. (Урбанавичюс Г. П., Урбанавичене И. Н., Отнюкова Т. Н. Phaeophyscia dissecta (Physciaceae, Lecanorales) - новый вид лишайника из Южной Сибири (Россия) // Бот. журн., 2007. Т. 92, № 11. С. 118-123).

Van Herk C. M., Aptroot A. 1999. Lecanora compallens and L. sinuosa, two new overlooked corticolous lichen species from western Europe. Lichenologist 31: 543-553. DOI: https://doi.org/10.1006/lich.1999.0216

Velmala S., Myllys L., Goward T., Holien H., Halonen P. 2014. Taxonomy of Bryoria section Implexae (Parmeliaceae, Lecanoromycetes) in North America and Europe, based on chemical, morphological and molecular data. Annales Botanici Fennici 51: 345-371. DOI: https://doi.org/10.5735/085.051.0601

Yazıcı K., Aptroot A. 2008. Corticolous lichens of the city of Giresun with descriptions of four species new to Turkey. Mycotaxon 105: 95-104.

Zhdanov I. 2012. New and rare lichen records from the Central Siberian Biosphere Reserve (Krasnoyarsk Krai, Russia). II. Folia Cryptogamica Estonica 49: 83-87. 